\title{
COMPARATIVE EFFECTIVENESS OF INTERNAL AND EXTERNAL MONITORING SYSTEMS REGARDING MONITORING STUDENTS' ATTENDANCE AT PRIMARY SCHOOL LEVEL IN DISTRICT BANNU
}

Wali Ahmad Khan ${ }^{1 *}$, Mati Ullah ${ }^{2}$, Irfan Ullah Khan ${ }^{3}$, Muhammad Altaf ${ }^{4}$, Muzammil Shah $^{5}$

${ }^{1 * 4,5}$ M.Phil Scholar, Department of Education \& Research, University of Lakki Marwat, KP, Pakistan; ${ }^{2}$ Lecturer, Department of Education \& Research, University of Lakki Marwat, KP, Pakistan; ${ }^{3}$ Assistant Prof. Department of

Education \& Research, University of Lakki Marwat, KP, Pakistan.

Email: ${ }^{1 *}$ waliahmad802@gmail.com, ${ }^{2}$ educationistmrn@gmail.com, ${ }^{3}$ thescholaredun @ gmail.com,

${ }^{4}$ Jazibb450@gmail.com, ${ }^{5}$ muzammilchemist353@gmail.com

Article History: Received on $28^{\text {th }}$ June 2021, Revised on $9^{\text {th }}$ July 2021, Published on $10^{\text {th }}$ July 2021

Abstract

Purpose of the study: The key purpose of the study was to compare the effectiveness of Internal and External Monitoring systems regarding students' attendance at primary school level Bannu.

Methodology: Descriptive survey design was used for this study. The data was taken from head Teachers through a selfdeveloped questionnaire of the 6-Likert scale. According to John Curry (1984) Sample size rule of Thumb, out of N= $650, n=65$ respondents was taken from district Bannu. A simple random technique was used, and also validity and reliability of the instrument were making sure in this study. Data were analyzed through SPSS by using Mean, Std. Deviation and t-test.

Main Findings: The main findings of the existing study shown that the officials of external monitoring are better in monitor the students' attendance, improving students' attendance during routine monitoring, priority-based check-up of primary school students attendance during official visits, and pointing out of students absentees while the internal monitoring officials perform better only regarding "encouraging school staff to motivate the regular students with the proper award".

Applications of this study: The existing study greatly significant for Educational administrators and monitoring departments, policymakers, Head Teachers, and the government which can find the real fact and issues about student attendance.

Novelty/Originality of this study: The current study is fairly new and unique in the field of education department of the monitoring system. The current study is the original research work of a researcher in the field of the education monitoring system of IMS and EMS/IMU.

Keywords: Internal Monitoring System (IMS), External Monitoring System (EMS)/Independent Monitoring Unit (IMU), Students' Attendance, Bannu.

\section{INTRODUCTION}

Education plays a vital role in the development of any country. That is why education is being valued all over the world. The current status of education in Pakistan is not satisfactory as compared to developed countries because Pakistan invests about two point three percent $(2.3 \%)$ of its GDP in the education sector (Pasha, 2020). This shows that the provincial and federal governments are not paying much attention to the education sector. After reviewing Pakistan's education policies, it has been observed that education in Pakistan has not achieved its goals for two main reasons. One of the reasons is not loyalty to the work while the other is non-implementation. The loyalty to work can be made possible by motivation while the implementation process can be made possible through better monitoring. Monitoring is an important and compulsory element of management that plays a very important role in decision making and improvement of any program which is continuous in any organization or institution (World Bank, 2007). Monitoring is a systematic process of gathering data, reviewing it, balancing it, and presenting it in its original position (Shah, 2009). Monitoring is a systematic and continuous process of collecting relevant data. It is also the name of observation of various activities, data, perspectives, and the presenter of the results accordingly. It also keeps in touch with top-level management and keeps save the same information for future evaluation (Shami, 2009).

Monitoring is a vital and supreme part of management for the successful completion of any new program in any organization (Shah, 2004). The monitoring system aware and show us the performance of any system because monitoring is a regular and routine process of any organization (Reid, 2006). Monitoring is critically observing all running activities in any institution. They judge all the concern activity if there are weaknesses in any area, report to high ups, and also $\mathrm{r}$ recommending high ups for improvement. They found monitoring as a systematic process for safe the record and determining the running program continuity on the pre-plan objective. If the running program going out of track they immediately highlight with the lower or concerned manager and also high light with upper-level administration (Oghuvbu, 2010). Primary schooling is a very important and difficult step to take in a better way. The Primary School stage is an example of a healthy seed that makes a tree and produces excellent fruit in the future. (Bradley, 2015). There is monitoring at every stage in our education system which is the responsibility of the local 
administration. Because of the monitoring of the same local administration, all aspects in the same school are functional. No organization can ever achieve its goals without proper monitoring. That is why all the developed countries in the world have excellent monitoring systems. To achieve the goals of quality education, it is necessary to have a monitoring system with an excellent system and the same monitoring consists of local education officers (Sekiwu, Ssempala, and Frances, 2020). The responsibility of education monitoring is that they form the objectives of education, determine the instrument, take steps to achieve the same objective, and then critically observe the on-going programs in the Education Institution for achievement the same objective, if all the activities are going according to the scheduled program, then they do not disturb the program otherwise they report to high up and suggest according to the situation (Morrissey, Hutchison and Winsler, 2014). Education monitoring takes place in the rest of the country of the world (Shah, 2004).

\section{OBJECTIVES OF THE STUDY}

The objectives of the study were:

1. To examine the concerns of School Heads about the effectiveness of EMS/IMU Officials regarding students' attendance at the Primary school level in district Bannu.

2. To determine the concerns of School Heads about the effectiveness of IMS Officials regarding students' attendance at the Primary school level in district Bannu.

3. To compare the concerns of School Heads regarding the effectiveness of EMS/IMU and IMS Officials regarding students' attendance at the Primary school level in district Bannu.

\section{LITERATURE REVIEW}

According to (Mahmood, 2017), the responsibility of monitoring the education department in Pakistan lays on the Education Department itself. According to this system of education, the responsibility of monitoring first falls on the head of the school. Because he is the immediate boss of the institution and always present at the institution during duty hours. Similarly, they always stay in touch with his senior officers all the time regarding his institution because of this responsibility; he has to answer to the senior officers in all matters of the school. Besides this those who responsible for monitoring the overall education system at the district level, it includes ASDEOs, SDEOs, DDEO, and DEO. (Government of Punjab, 2001) explained that District Education Officer (DEO) is responsible to the Director of Elementary and Secondary Education for all education-related programs throughout running in the district. The DEO is in the position at the top-level management in the education system at the district level while the ASDEOs (Lower level management) are responsible for internal monitoring in the field at the primary school level. The DEO and SDEO also supervise Internal Monitoring (ASDEOs).

(Ashfaq, 2014) found that quality education must have a monitoring system in which the data match the reality of the data field. To achieve this goal, in 2014 PTI government introduced a monitoring system named Independent Monitoring unit in the KPK education system. In IMU monitors function as the Data collection \& Monitoring Assistant (DCMA). They visit three or four schools daily, it has an Android mobile. (Muhmood, 2015) narrated that the monitoring assistant forwards the report according to the prescribed proforma in the mobile which contains various indicators. The Independent Monitoring Head on the district level is in the District Monitoring Officer (DMO) who responds or in control of the secretary of education. (McCutcheon, 2007) explained that the monitoring system must be authorized, strengthen, and unbiased for quality education because the monitoring system shows the data of the institution, which is the real face of any institution, after the collection of data they critically observe and then analyze based on the past data of the same institution, steps are taken for future improvement in the current position where drawback highlight. (O'Neil, 2021) asserted that Pakistan's total literacy rate was around 59 percent, which is much lower as compared to developed countries in 2017. (Farooq, Feroz and Tong, 2017) revealed that there are many reasons for our country's poor education system.

(Ashraf and Hafiza, 2016) described that poor and low education system includes teacher absenteeism, lack of educational funds, lack of physical facilities, extreme poverty, and not proper digitalize monitoring. In Pakistan students' attendance still very low at the primary school level because the dropout rate in 2014 was $68 \%$ and in 2015 was $65 \%$ which is very high as compared to developed countries. (Haidar, 2016) highlighted that the education system of Pakistan still needs further improvement and enhancement to meet to ensure social justice, political stability, socio-economic development, demolishing gender disparity, and elevation of poverty. (Haidar and Fang, 2019) elaborated that students' dropout, their attendance issues, teachers' truancy (absenteeism), and unequal access to educational resources, low school efficiency, and low literacy rate are the key issues in the education system. (Ali \& Hussain 2020) mentioned that as IMU was established in 2014 but IMU improved the attendance of both teachers and students at school level by $13 \%$ and $24 \%$ and 300 teachers were terminated from their services due to their routine absenteeism; furthermore, 8000 disciplinary actions were taken by the department against teachers and 200 million funds were recovered via various resources. (Ford and Sutphen, 2016) described that it is very important for the government to encourage the school leaders and managers to polish and further improve the existing system of monitoring or internal monitoring system to ensure the quality of education. Similarly through internal monitoring department (management cadre) try to achieve the set goal of quality education which is more improve through new recruitment of schools leader (managers). (Karande 
and Kulkarni, 2017) stated that students' dropout and poor attendance include uninteresting teaching materials, overburdened curricula, absence of interest in the teaching-learning process, paternal illiteracy, absence of co-curricular happenings, school-home distance, and absence of governmental attention. Similarly investigated that students' regular attendance is very essential for the quality teaching-learning process at the school level; students' regular attendance and learning outcomes are positively associated.

\section{RESEARCH HYPOTHESIS OF THE STUDY}

$\mathbf{H}_{\mathbf{0}}$ : There is no significant difference between the concerns of School Heads regarding the effectiveness of EMS/IMU and IMS Officials regarding students' attendance at the Primary school level in district Bannu.

\section{RESEARCH METHODOLOGY}

\section{Research Design}

A descriptive survey design was used for this study in light of the objectives of the study.

\section{Population}

The population of the study constituted all Primary Schools in District Bannu.

\section{Target Population of the Study}

All School Heads were the target population of the study that was ( $\mathrm{N}=650$, Source: Education Office).

\section{Sample of the Study}

The total numbers of $(n=65)$ respondents were taken as samples of the study out of $(\mathrm{N}=650)$ respondents according to John Curry sample size rule of thumb as shown in the table below:

Table 1: Sample of the Study

\begin{tabular}{lll}
\hline Locality & Respondents (Head Teachers ) & Sample (n) \\
\hline District Bannu & 650 & 65 \\
\hline
\end{tabular}

\section{John Curry (1984) Sample size rule of Thumb}

\section{Population Size Sample Size}

10-100

$100 \%$

101-1000

$10 \%$ (Sample falls in this category)

1001-5000

$5 \%$

$5001-10000$

$3 \%$

$10000+$

$1 \%$

\section{Sampling Techniques}

Simple random and stratified sampling techniques were used.

\section{Research Instrument}

A self-developed questionnaire of 6-points Likert scale of options Strongly Agree, Agree, Slightly Agree, Slightly Disagree, Disagree, and Strongly Disagree carrying values 1, 2, 3, 4, 5, and 6 were used to collect data from the respondents.

\section{Pilot Testing}

The validity and reliability of the research instrument were ensured. The research instrument was validated by field experts and for reliability; 30 copies of the questionnaire were distributed among the respondents (School Heads). Cronbach's Alpha was applied to calculate the internal consistency of items i.e. 0.984 which was excellent.

\section{DATA ANALYSIS}

The collected data were statistically analyzed through SPSS by using Mean, Std. Deviation and t-test. T-test was used to compare Internal and External Monitoring systems regarding students' attendance.

\section{RESULT OF THE STUDY}

Table 2: Officials Monitoring Regarding Students Attendance

\begin{tabular}{|c|c|c|c|c|c|}
\hline \multirow{2}{*}{ Statement } & IMS & & EMS & & \\
\hline & Mean & S.D & Mean S.D & t-value & P-value \\
\hline
\end{tabular}




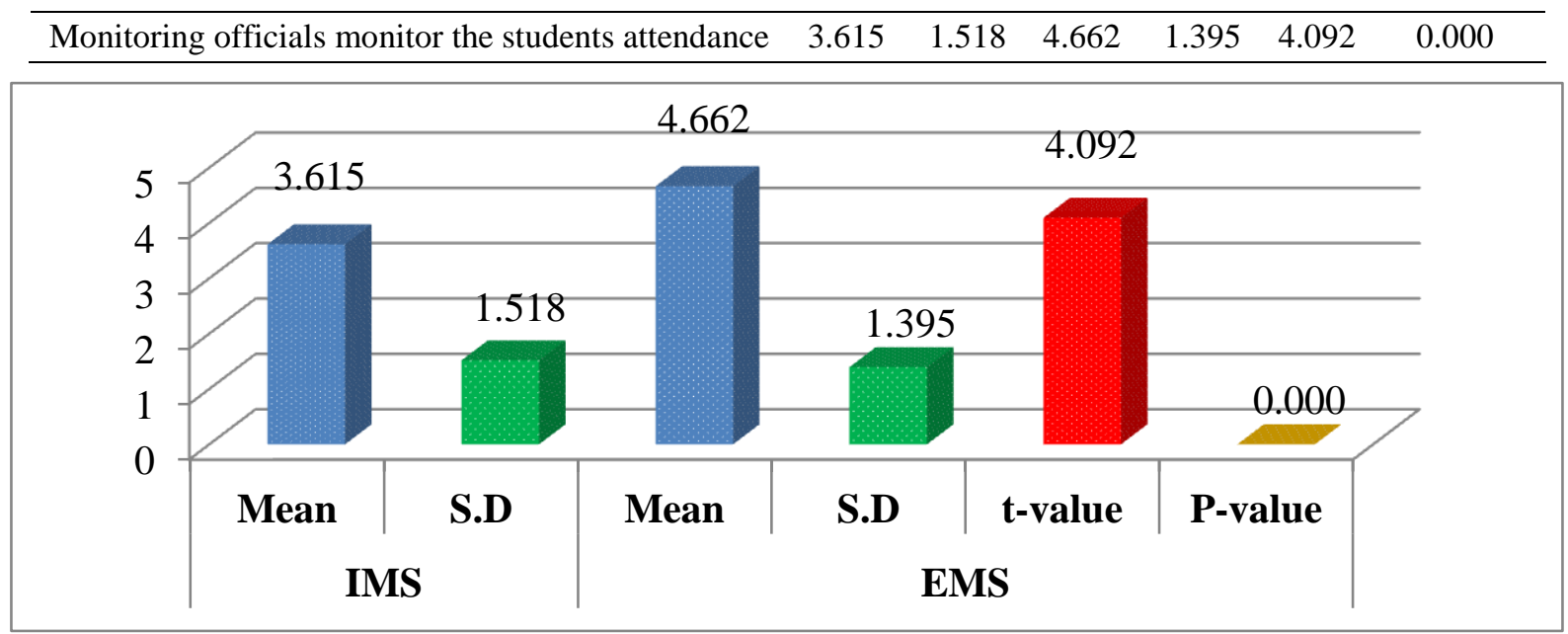

Figure 1: Showing Officials Monitoring Regarding Students Attendance

The above table shows the comparison of students' attendance concerning internal monitoring and external monitoring systems at the primary school level in district Bannu in which the monitoring officials of external monitoring system better monitor students attendance as compared to officials of an internal monitoring system according to the statistical result shown in the table above where the mean score of external monitoring system (EMS) about monitoring students attendance is 4.662 , Std. The deviation is 1.395 that is greater than the mean value of the internal monitoring system (IMS) i.e. 3.615, with Std. Deviation 1.518. As p-value is 0.000 which is less than the alpha value $(0.05)$ while the tvalue is 4.092 which statistically shows a significant difference regarding the said statement.

Table 3: Routine Monitoring and Improvement in Students' Attendance

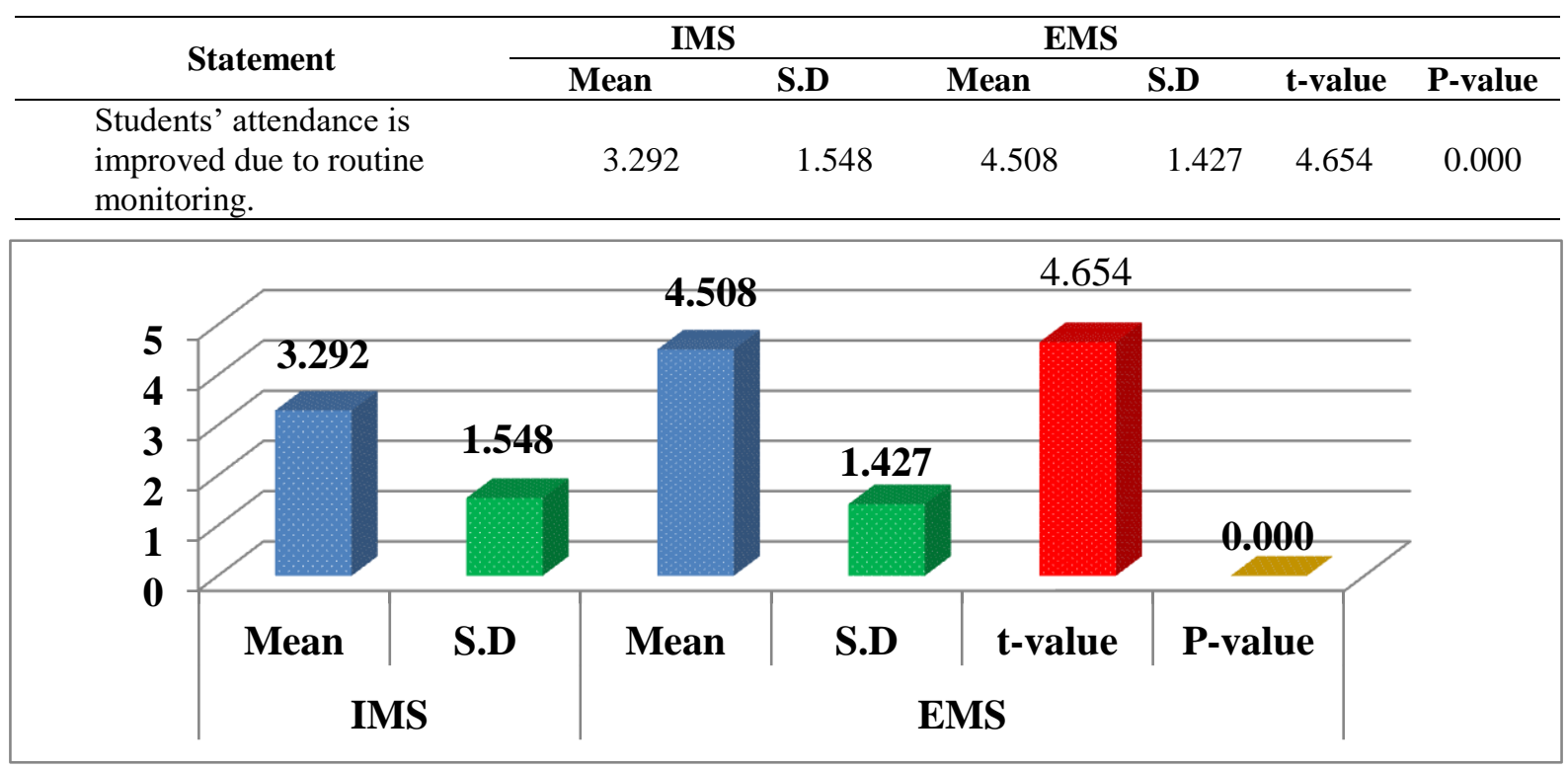

Figure 2: Showing Routine Monitoring and Improvement in Students' Attendance

Table 3 along with the graph show that the comparison of students' attendance concerning internal monitoring and external monitoring systems at the primary school level in district Bannu in which the monitoring officials of external monitoring system better in "Students' attendance is improved due to routine monitoring" as compared to officials of an internal monitoring system according to the statistical result shown in the table above where the mean score of external monitoring system (EMS) is 4.508, Std. The deviation is 1.427 that is greater than the mean value of the internal monitoring system (IMS) i.e. 3.292, with Std. Deviation 1.548. As p-value is 0.000 which is less than the alpha value (0.05) while the t-value is 4.654 which statistically shows a significant difference regarding the said statement.

Table 4: Monitoring of Students Attendance on Priority Basis

\begin{tabular}{|c|c|c|c|c|c|c|}
\hline \multirow{2}{*}{ Statement } & \multicolumn{2}{|c|}{ IMS } & \multicolumn{2}{|c|}{ EMS } & \multirow[b]{2}{*}{ t-value } & \multirow[b]{2}{*}{ P-value } \\
\hline & Mean & S.D & Mean & S.D & & \\
\hline $\begin{array}{l}\text { They check the attendance of } \\
\text { students on a priority basis } \\
\text { during their routine visits. }\end{array}$ & 3.231 & 1.647 & 4.923 & 0.907 & 7.258 & 0.000 \\
\hline
\end{tabular}




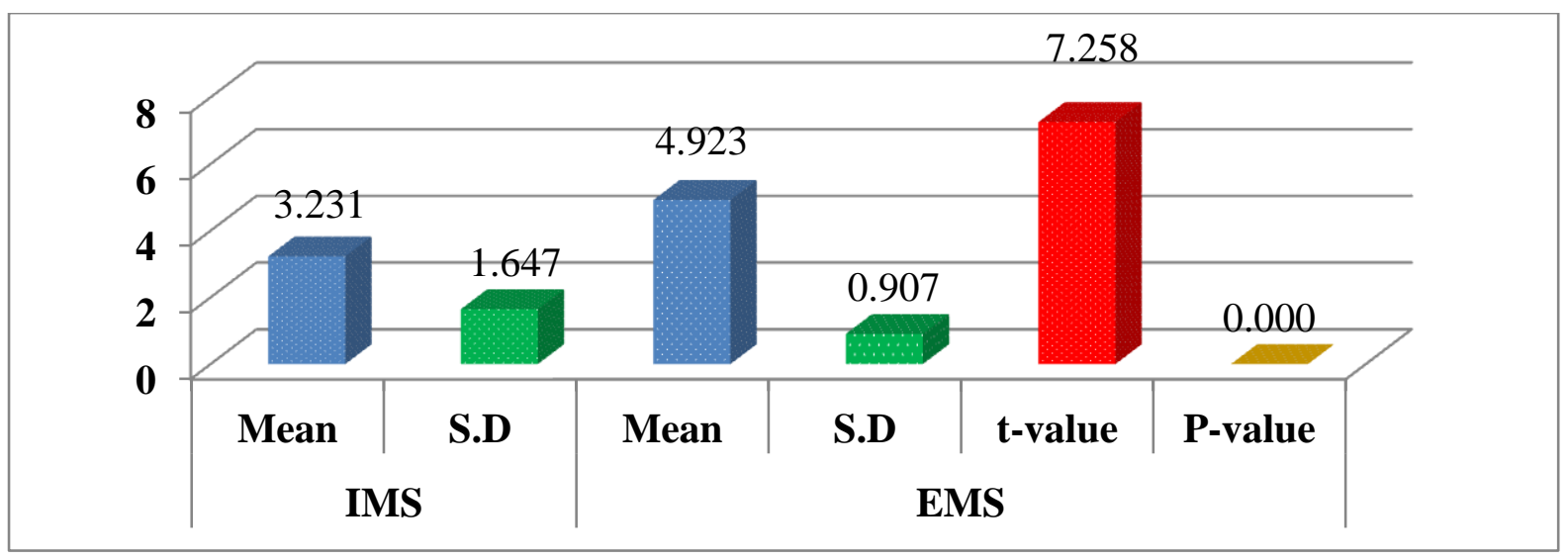

Figure 3: Showing Monitoring of Students Attendance on Priority Basis

Table 4 along with the graph indicate that the comparison of students' attendance concerning internal monitoring and external monitoring systems at the primary school level in district Bannu in which the monitoring officials of external monitoring system perform better about the statement "They check the attendance of students on priority basis during their routine visit" as compared to officials of an internal monitoring system according to the statistical result shown in the table above where the mean score of external monitoring system (EMS) is 4.923, Std. The deviation is 0.907 that is greater than the mean value of the internal monitoring system (IMS) i.e. 3.231, with Std. Deviation 1.647. As p-value is 0.000 which is less than the alpha value (0.05) while the t-value is 7.258 which statistically shows a significant difference regarding the said statement.

Table 5: Monitoring Officials and Students Absentees

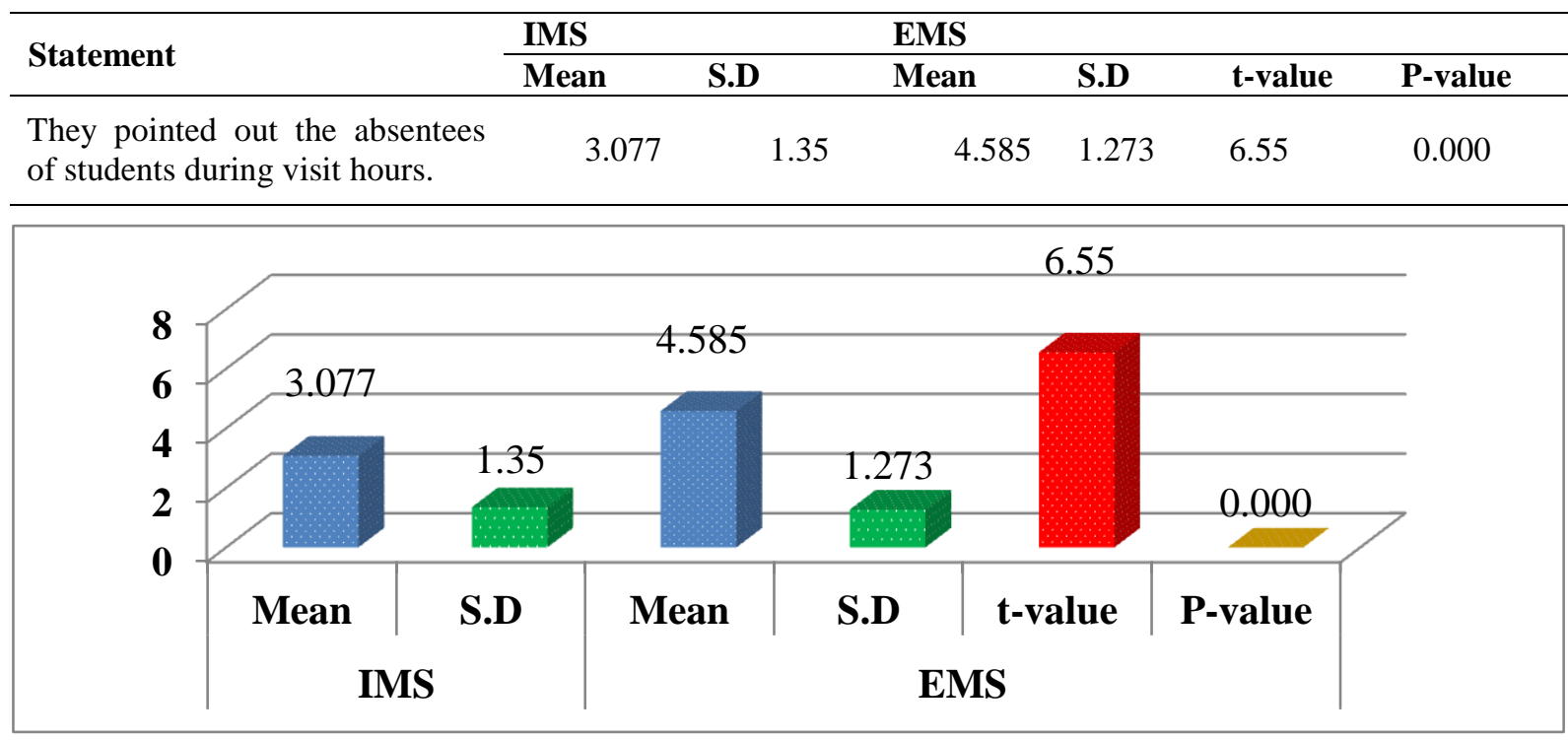

Figure 4: Showing Monitoring Officials and Students Absentees

Table 5 along with the graph revealed that the comparison of students' attendance to internal monitoring and external monitoring systems at primary school level in district Bannu in which the monitoring officials of external monitoring system perform better about the statement "They pointed out the absentees of students during visit hours." as compared to officials of an internal monitoring system according to the statistical result shown in the table above where the mean score of external monitoring system (EMS) is 4.585 , Std. The deviation is 1.273 that is greater than the mean value of the internal monitoring system (IMS) i.e. 3.077, with Std. Deviation 1.35. As p-value is 0.000 which is less than the alpha value (0.05) while the t-value is 6.55 which statistically shows a significant difference regarding the said statement.

Table 6: Monitoring Officials Emphasizing School Staff for Rewarding Regular Students

\begin{tabular}{llccccc}
\hline \multirow{2}{*}{ Statement } & \multicolumn{1}{c}{ IMS } & EMS & & \\
\cline { 2 - 7 } & Mean & S.D & Mean & S.D & t-value & P-value \\
\hline $\begin{array}{l}\text { They emphasize school staff to } \\
\text { encourage the regular students } \\
\text { with proper awards }\end{array}$ & 2.923 & 1.762 & 2.692 & 1.6 & 0.782 & 0.436 \\
\hline
\end{tabular}




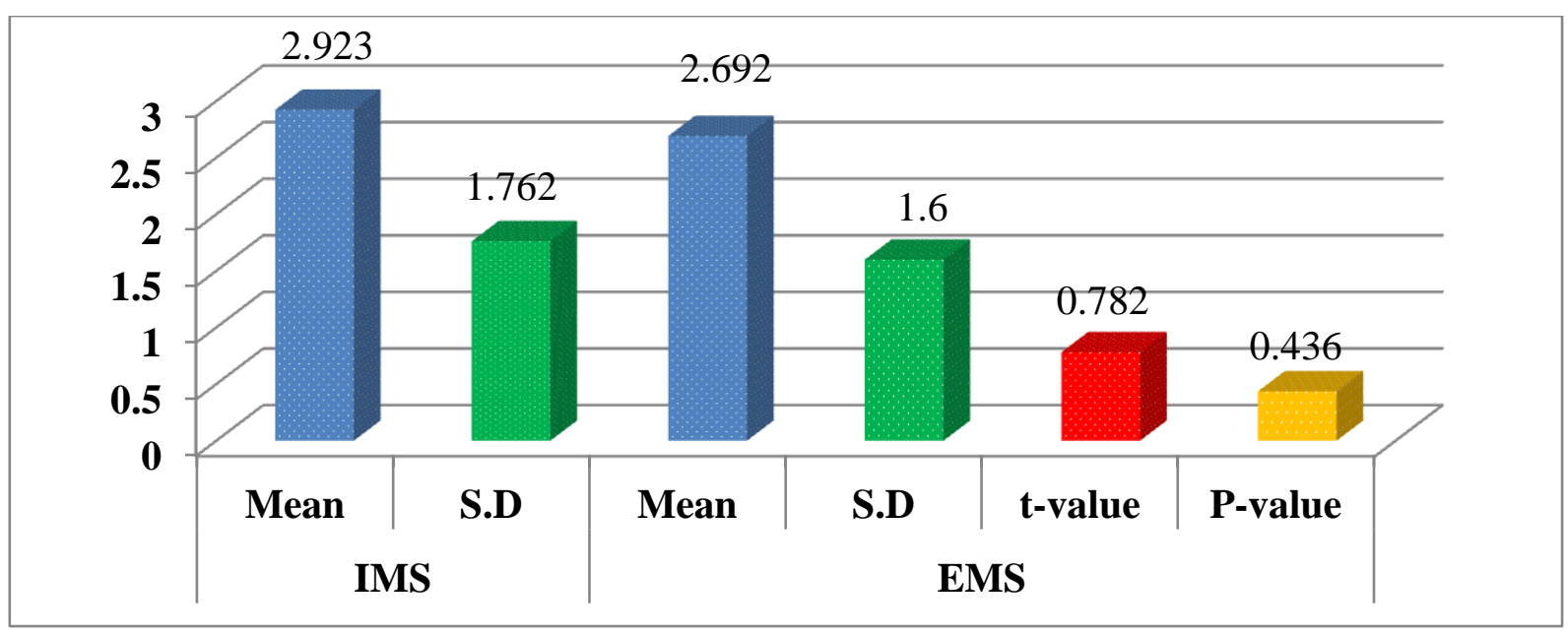

Figure 5: Showing Monitoring Officials Emphasizing School Staff for Rewarding Regular Students

Table 6 along with the graph shows that the internal monitoring officials perform better only than external monitoring officials regarding "encouraging school staff to motivate the regular students with the proper award" as per statistical result is the mean value of internal monitoring system official is 2.923 , Std. Deviation 1.762 whereas the mean value of officials of the external monitoring system is 2.692 , Std. Deviation as p-value is 0.436 greater than alpha value (0.05) with $\mathrm{t}$-value 0.782 which shows insignificant difference regarding encouraging school staff to motivate the regular students with proper award.

\section{DISCUSSION}

The current study is regarding students' attendants at the Primary School level in District Bannu concerning internal monitoring and external monitoring systems indicates that the monitoring officials of external monitoring system were more careful and sincere about ensuring students' attendance including (monitor students attendance, improving students attendance due to routine monitoring, routine monitoring, priority-based check-up, and pointing out of students absentees) at primary school level as compared to the official of internal monitoring system while the officials of internal monitoring system were found quite sensitive and conscious regarding emphasizing school staff to encourage the regular students with proper awards.

According to the previous study by (Muhmood, 2015) revealing in his thesis title "Comparative Effectiveness of Internal and External Monitoring Systems in Punjab Education Department" that internal monitoring systems perform better than external monitoring systems regarding students' attendance. (Jatoi, 2010) found in his study "Non-Functional schools in Pakistan: Does Monitoring System have an Impact?” that student enrolment is positively associated with their regular attendance.

(Akinduyite et al., 2013) found that there is a need for a better attendance monitoring system of students to ensure consistency and reliability in the attendance record of students. (Shoewu and Idowu, 2012) narrated that it's obligatory and mandatory upon parents to share their latest updates with the teachers or school administration regarding the attendance of their children throughout the session by taking help from monitoring staff in this regard. (Chandramohan et al., 2017) highlighted that both internal and external monitoring officials emphasize school teachers to ensure students' daily attendance and encourage students about their regularity in school. (Zainal et al., 2014) described that monitoring officials may encourage the government to facilitate school students with their routine school activities like long, short breaks or recess, canteen, better prosperous environment, and other such facilities that could ensure students' regularity towards their schools so that students' attendance may be maximized at school level. (Ali and Hussain, 2020) revealed that internal and external monitoring officials are advised to coordinate and assist one another about students' attendance at their schools by sharing their views and opinions with the school staff to either fully improve students' attendance or to reduce to a minimum level. (Clercq, 2009) asserted that monitoring officials may give priority to biometric fingerprints not only for teachers but also for students to technologically enhance and ensure students' attendance at the school level.

\section{CONCLUSIONS}

The researcher concluded by keeping in view the results and discussion of his study that the officials of external monitoring (EMS) better performed as compared to the internal monitoring system (IMS) students' attendance in different ways i.e. they monitored the students' attendance; they did their best by improving students' attendance through routine monitoring; they checked students' on priority basis during their routine visit, and they also pointed out the absentees of students during their visit hours but only Internal Monitoring System (IMS) positively and betteremphasized school staff to encourage the regular students with proper awards. 
To sum up, the researcher concluded that the Officials of the External Monitoring System/IMU Officials were found quite active and practical regarding bringing quality improvement in students' attendance at the Primary school level in district Bannu, KP, Pakistan. Officials of the Internal Monitoring System were in favor of emphasizing school staff to ensure the quality of primary school students' attendance by awarding them rewards for the sake of their encouragement towards regularity.

\section{RECOMMENDATIONS}

The following recommendations were drawn in the light of objectives and results of the study:

1. The Competent Authority may ensure the real fact about students' attendance through students' attendance via attendance registers during ASDEO's visit to the Primary schools as per advice given to them.

2. The Officials of the Internal Monitoring System (IMS) may properly check students' attendance on a priority basis during visit hours to improve the quality of students' attendance at the primary school level.

3. The Officials of the Internal Monitoring System may point out the absentees' cases in this regard either to ensure regularity or reduce absenteeism at all so that teachers may take the visit of Education Officers seriously regarding students' attendance or students' presence.

4. The government of the day may provide proper training and workshops regarding students' attendance.

5. The External Monitoring System Officials may encourage school staff to reward students for their regular attendance as practices ensured by the Officials of the Internal Monitoring System in this regard.

\section{LIMITATIONS OF STUDY}

The study was limited just to Internal and External Monitoring Systems at the Primary School level in Districts Lakki Marwat and Bannu.

The study may be extended to Middle and Secondary School levels by adding some mediators and moderators by ensuring proper time limit and resources to attain the desired goal.

A qualitative study including interviews may be conducted to record the views and responses of the respondents regarding the Internal and External Monitoring System.

The objectives achieved in this study provide significant insight into the specific context; nevertheless, it can be extended to other private schools also to extract new knowledge about existing issues.

\section{SUGGESTIONS FOR FUTURE RESEARCH}

Future researchers are advised to extend the study by extending the sample size to find out a better solution to the current issues/problems in internal and external monitoring systems.

Future researchers are suggested to add more predicting and mediating variables to extract the significant data as per the nature of the study.

\section{SIGNIFICANCE OF THE STUDY}

The following were the significances of the study for the government, policymakers, students, teachers, and education department, Monitoring Systems at school level, researchers and educationists to take insight from this study to bring quality improvement in the education system at the Primary school level.

1. The study may be helpful for all stakeholders such as DEOs, DDEOs, SDEOs, ASDEOs, and District Monitoring Officers (DMOs)

2. The study may be very significant for the government to take necessary action against the defaulters in this regard.

3. The study may be quite vital for Khyber Pakhtunkhwa Elementary \& Secondary Education Department (KPESED) to strengthen the monitoring and implementation system in education.

4. The study may be very important for the Provisional Government to take corrective measures in the education department.

5. The study may be very beneficial for the policymakers and planners to formulate plans and policies for the betterment of education at the school level.

\section{AUTHORS' CONTRIBUTION}

Mr. Wali Ahmad (M.Phil Scholar) is the principal contributor by providing the unique and conceptual theme of the study. Dr. Irfan Ullah Khan and Dr. Mati Ullah contributed to statistical procedure and analysis via SPSS. Mr. Muhammad Altaf and Mr. Muzammil Shah (M.Phil Scholars) did drafting and revised the manuscript. 


\section{REFERENCES}

1. Ali, A., \& Hussain, I.A., (2020). The Effects of Independent Monitoring Unit at the Performance of Primary Schools in Khyber Pakhtunkhwa. The Dialogue, 15(2), 1-9.

2. Ashfaq, M. (2014). Independent monitors to oversee school affairs in KP. The Dawn Today's papers/January 23, 2014, retrieved today's paper/Jun 23, 2021.

3. Ashraf, M. A., \& Hafiza, I. I. (2016). Education and Development of Pakistan: A Study of Current Situation of Education and Literacy in Pakistan. US-China Education Review, 6(11). 647-654. https://doi.org/10. $17265 / 2161-6248 / 2016.11 .003$

4. Mahmood, Z. (2017). Comparison of internal and external monitoring systems in terms of students' attendance, enrollment, and retention in Punjab Education Department-Pakistan, J. Appl. Environ. Biol. Sci., 7(8), 58-67.

5. Farooq, M.S., Feroz, N., \& Tong, Y. (2017). Public vs. private quality education at primary level in Pakistan. International Online Journal of Primary Education, 6(2), 1-23.

6. Government of Punjab (2001). Punjab Education Sector Reform Programme - (PESRP). Department of School Education. http://www.pesrp.edu.pk/pmiu.php?v=programs dated: 22/11/2009

7. Haidar, S. (2016). Passport to Privilege: Access to English in Different School Systems in Pakistan (Unpublished Ph.D. Dissertation). The University of Rochester.

8. Haidar, S., \& Fang, F. (2019). Access to English in Pakistan: a source of prestige or a hindrance to success. Asia Pacific Journal of Education, 39(4), 485-500. https://doi.org/10.1080/02188791.2019.1671805

9. Jatoi, H. (2010). Non-Functional schools in Pakistan: Does Monitoring System has an Impact? 1-102.

10. Karande \& Kulkarni (2017) Micro-consequences of high fertility: The case of child schooling in rural Pakistan, 415-444.

11. McCutcheon, S. (2007). Punjabi Reforms www.UNDP.org/pk dated 04/03/2010

12. Bradley, R. R. (2015). A Comprehensive Approach to Improving Student Attendance. Unpublished Doctor of Education Thesis. St.John Fisher College. https://fisherpub.sjfc.edu/education_etd/225

13. Muhmood, Z. (2015). Comparative Effectiveness of Internal and External Monitoring Systems in Punjab Education Department. 1-340.

14. O'Neil, A. (2021). Literacy rate in Pakistan 2017. Statista; https://www.statista.com/statisti cs/572781/literacyrate-in-pakistan/

15. Pasha, F.R. (2020). Education Budget of Pakistan. Pakistan Alliance for Girls Education, https://page.org.pk/education-budget-of-pakistan/

16. Shah, D. (2004). Decentralization in the Education System of Pakistan: Policies and Strategies. Islamabad: MOE. Academy of Education Planning and Management.

17. Shah, D. (2009). Monitoring the Quality of Secondary Education in Context of Decentralization in Pakistan. Lahore: Bulletin of Education and Research, IER, University of Punjab. 31(1), 1-25.

18. Shami, P.A. (2009). Educational Leadership and Institutional Management, Islamabad: AEPM, MOE.

19. Ford, J., \& Sutphen, R. D. (2016). Early intervention to improve attendance in elementary school for at-risk children: A pilot program. Social Work in Education, 18(2), 95-102. https://doi.org/10.1093/cs/18.2.95

20. World Bank (2007). Monitoring and Evaluation Development Project- the South Asian Experience, Economic Development Institute. www.worldbank.org dated 04/04/2010

21. Akinduyite, C. O., Adetunmbi, A. O., Olabode, O. O., \& Ibidunmoye, E. O. (2013). Fingerprint-based attendance management system. J. Comput. Sci. Appl., 1(5), 100-105. https://doi.org/10.12691/jcsa-1-5-4

22. Shoewu, O., \& Idowu, O. A. (2012). Development of attendance management system using Biometrics. Pacific J. Sci. Technol., 13(1), 300-307.

23. Chandramohan, J., Nagarajan, R., Ashok-kumar, M., Dineshkumar, T., Kannan, G., \& Prakash, R. (2017). The attendance monitoring system of students based on biometric and GPS tracking systems. International Journal of Advanced Engineering, Management, and Science (IJAEMS), i(3), 241-246. https://doi.org/1 0.24001/ijaems.3.3.16

24. Zainal, N.I., Sidek, K.A., Gunawan, T.S., \& Martini, H.M.M. (2014). Design and development of portable classroom attendance system based on Arduino and fingerprint Biometric, IEEE International Conference on Information and Communication Technology for the Muslim World, Nov. 17-18. https://doi.org/10.11 09/ICT4M.2014.7020601

25. Ali, A., \& Hussain, A.I. (2020). The effects of independent monitoring unit at the performance of primary schools in Khyber Pakhtunkhwa. The Dialogue, 15(2), 1-9.

26. Clercq, F. (2009). School monitoring and change: a critical examination of Whole School-Evaluation. Education as Change, 11(2), 97-113. https://doi.org/10.1080/16823200709487168

27. Reid, K. (2006). Raising school attendance: a case study of good practice in monitoring and raising standards. Quality Assurance in Education, 14(3), 199-216. https://doi.org/10.1108/09684880610678531

28. Oghuvbu, E. P. (2010). Attendance and academic performance of students in secondary schools: A correlational approach. Studies on Home and Community Science, 4(1), 21-25. https://doi.org/10.10 $\underline{80 / 09737189.2010 .11885294}$ 
Humanities \& Social Sciences Reviews elSSN: 2395-6518, Vol 9, No 4, 2021, pp 15-23

https://doi.org/10.18510/hssr.2021.944

29. Sekiwu, D., Ssempala, F., \& Frances, N. (2020). Investigating the relationship between school attendance and academic performance in universal primary education: The case of Uganda. African Educational Research Journal, 8(2), 152-160. https://doi.org/10.30918/AERJ.82.20.017

30. Morrissey, T. W., Hutchison, L., \& Winsler, A. (2014). Family income, school attendance, and academic achievement in elementary school. Developmental Psychology, 50(3), 741-768. https://doi.org/10. $\underline{1037 / \mathrm{a} 0033848}$ 